http://www.jfas.info

\title{
REVIEW THE PERFORMANCE OF BROKERAGE FIRMS AND THEIR ROLE ON INCREASING INVESTMENT TRUST AND THE DEGREE OF STOCK LIQUIDITY
}

\author{
M. Miransari \\ MSc of Financial Management, sama technical and vocatinal training college islamic azad \\ university sabzevar branch sabzevar iran
}

Published online: 16 July 2016

\begin{abstract}
The main goal of present study is to review the performance of brokerage firms and their role on increasing investment trust and stock liquidity degree, in this regard, the role of brokerage firms is studied on increasing investors' trust and stock liquidity degree by utilization of four independent variables (providing general and specific services, customer orientation, using updated technologies and using standards and managerial forms). The population is the brokerage firms in Tehran stock Exchange until end of year 2012, 107 brokerage firms in Khorasan province have been studied as samples. Tools for data collection were a questionnaire made by the researcher analyzed through SPSS software. The results indicated positive and significant relation among research variables.
\end{abstract}

Key words: the performance of brokerage firms, investment trust, stock liquidity degree.

Author Correspondence, e-mail: sab.imengostar@gmail.com

doi: http://dx.doi.org/10.4314/jfas.v8i2s.100

\section{INTRODUCTION}

Growth and development of any country requires utilization of resources in optimized form and conducting them to the right path. In every society, different institutions can head into this goal to have an effective role in this regard. 
Investment market and related institutions are the most important effective factors in this process, in a way that, nowadays the performance of investment market has been utilized within developed countries as an index for assessing policies, financial, economic and commercial changes of countries. Continuum of stock exchange in every country is considered as continuum of growth and economic improvement. Sock exchange as an official market is the most important factor of absorption and proper systematizing wandering financial resources and provides significant economic profit in addition to move the wheels of economy by collecting society's liquidity and selling companies' stocks and besides it vanishes the impacts of inflation due top availability of liquidity within society. The main duty of stock exchange is to provide a clear and fair market for business also it is system for supervising trades, market process and the activity of its members and its fundamental feature is to legal support from the owners of deposit and legal obligations for capital applicants. Therefore, designing and distributing new financial tools, increase of public culture and knowledge level for stock exchange market, deterring fraud measures and misuse, increasing clarity and improving the information for all about progressive determining parameters in every exchange market. But financial intermediaries are having a useless intermediary among buyers and sellers of stock exchange and they have affected any modification, development and progress of performances. Therefore, reviewing the performance of financial intermediary companies and brokerage firm within advanced stock exchanges are drawing the significance to developing financial markets. Present study, regarding to the significance of the subject, reviews the performance of brokerage firms and it hopes to provide a useful improvement for financial intermediaries within Iran.

\section{The hypothesis of the study:}

Based on the theoretical analysis and review of the literature in this research, the hypotheses are mentioned below:

First hypothesis: providing general and specific services by brokerage firms is effective on increasing investment trust and increasing stock liquidity.

Second hypothesis: customer orientation of brokerage firms is effecting on increasing investment trust and increasing stock liquidity.

Third hypothesis: utilized latest technologies within brokerage firms are impacting on increasing investment trust and increasing stock liquidity. 
Fourth hypothesis: using services standardization and managerial forms is impacting on increasing investment trust and increasing stock liquidity.

\section{Literature:}

\section{Brokerage firms}

Brokers are legal and actual people that are playing intermediary role between buyer and seller within stock exchange market. They are responsible for this role for finding buyer for sellers and seller for buyers. In other words, they are the factor of adjusting supply and demand and they are divided into two categories of private and governmental. Buy and sale of stock exchange firms within market is only possible through official brokers of stock exchange organization; and this issue provides market trades clarity. Since the information relating to trades like, the number of stocks, the value of trade and the number of buyers and sellers is accessible every day. The brokers are chosen through several specific tests and they receive their certificate for founding and their activities from the organization of stock exchange, therefore, they have the competency, skill and adequate knowledge in their tasks. Brokers enter to the market through their customer account and they do trades on behalf of them. Therefore, regarding the nature of brokers' efficiency, these people shall consider ethical necessities like honesty and trustworthy $n$ addition to having skill, experience and intelligence.

\section{Performance review and ranking of brokerage firms}

Performance assessment is a process that the activity and performance of employees are measured via them and when it is done properly the employees, supervisors, managers and ultimately the organization will use it. there are different criteria about performance assessment of brokers that the most important ones are: companies financial assessment, companies efficiency assessment, organizational effectiveness, organization perfection, balanced performance (BSC), their rankings, there is no many studies internationally and in this study, quantitative models like data covering analysis, accidental border models and etc. are utilized.

In a total categorization, the Islamic financial services institutions are dividing into two categories mentioned below:

1) Monetary market which includes Islamic banks and non-banking institutions and the insurance service providing firms.

2) Capital markets including stock market and Skuk and infrastructural institutions like rating agencies and the companies which provide legal and accounting standards (Azar et al, 2012). 
Islamic economy system is highly different from other systems. Therefore, western concepts, ideas and their tools are not working without fundamental changes. Ethical values and Islamic ethical norms are highly impacting on the mode of Muslims' economic behavior within Islamic society. In a way that economics is a behavioral science, and it shall reflect Islamic behavior. The thing that distinguishes Islamic economy is its value system that impacts the decisions of consuming, production, saving, investment and re-distribution. In all above items that are known as the financial principles of Islam, we can consider below indexes for reviewing performance: social responsibility, clarity, organizational legitimacy (Sheikh et al, 2011)

\section{Factors affecting investors}

tendency of people toward a context or a specific issue, result-having of awareness and knowledge toward it and humans as consumers are choosing products and services that they know better, they are more aware of their functions and quality and they trust them more. Payable notes, as a kind of goods, are not exceptional. Merton believes that investors are indicating more tendencies to owning payable notes that they are aware more about them (Merton, 1987). Regarding the highly effective role of stock exchange in social and economic growth and development, stock exchange organization of country is having high responsibility on achieving regime goals and it shall try to utilize all its facilities and abilities to achieve the tests of country more and more. Therefore, there are many factors are impacting on people to do investment on payable notes. The most important factors are Efficiency, publicity (information), reference groups, shareholdings culture, economic and political factors, and the availability of investment place.

\section{Building trust and confidence patterns}

Building trust is one of the key factors of rules within financial markets. Trust in trading system and brokers, trust on fair prices, trust on available information, trust in the managers of stock firms and their auditors and ... then the laws will be submitted to provide sense of security for participants within financial markets. The most important communication channel that is more active in making connection with investors is the companies' public relations. The related literature to "visibility" indicates that most of payable notes are neglected by investors since they are not seen by people and the active members of market are not adequately aware of their availability. Getting in touch is founded based on the hypothesis of investor recognition by 
Merton that states the investors shall be at least aware of the existence of firm and its financial assets within market (Merton, 1987).

\section{Liquidity and related factors}

Liquidity is the ease of buy or selling goods without a considerable change in its price (Golsten and Milgram). In financial texts in order to reach to the concept, they utilize the term "Marketability" or "Merchantability"; since the more the number potential sellers and buyers of an asset, the asset is more close to become cash. Liquidity has got many criteria; none of them are able to measure it comprehensively (Robin, 2007). Liquidity features can be divided into two groups mentioned below:

a) Criteria based on deal: Turnover, frequency of trades and value of shares traded

b) Criteria based on order: suggested price different between supply and demand, the difference of effective and deep supply and demand

\section{Literature:}

Adel Azar et al in 2012, have extracted the indexes of professions' performance and have ranked brokerage firms by using the models of CCR, BCC, AP through the literature review of Islamic financial within other countries regarding practical indexes of Islamic financial services institutions and poll from Iran capital market experts.

In other article, Sheikh et al (2011) have assessed the performance of brokerage firms by using fuzzy EHP and Topsis. They have utilized from 24 financial and non-financial criteria.

Omid Mokhtarian in his research during 2004 about the effective factors on investors' decision makings have concluded that the price flow of stocks for investors is more important issue rather than famous return and profit factors of each single stock. It indicates that financial ratios are not having a high position among investors.

Betacharia et al (2012) have reviewed the relation between interest quality and liquidity of New York and Nazdak stock Exchange firms' shares during 1998 -2005 and they have concluded that the lower being of interest quality causes imbalance increase and as a result it decreases stocks' liquidity.

Warnrid (2001) has done a research about the financial psychological features of investors to better understand investors' financial decision making and financial markets. But his study is less focusing investors' behavior and investment areas; he mentioned that there is a strong communication ring between investment choice and investors' behavior. 


\section{Methods:}

In order to assess the performance, first we codify and determine the indexes of performance assessment of such firms by using the idea of experts and also the viewpoint of brokerage firms; then in form of a questionnaire, it is asked from such firms to reply the questions and mention the significance of each criterion. Then the performance of brokerage firms will be assessed. Totally theoretically this study is an evidential research and inferentially it is posteriori one. Also this study is a semi-experimental in field of financial accounting studies and it is an applicable one. In this study, the part which is referring to codification of theoretical principles is done through library method by reviewing books, articles and theses. The part which was in connection with variables collected from CDs and available software.

\section{Statistical Population:}

Research population includes Khorasan Province brokerage firms which were in stock exchange market till end of 2012; the size of sample includes 107 brokerage firms within Khorasan province.

\section{Data collection}

The step of procedural start data collection, the step that the researcher collects his findings and compacts them in deductive method through classification and then analyzing them and assesses the codified hypotheses and ultimately he will determine a rule and finds a reply for his study according to it. Determining data collection tools is done by using selected method. in other words, each method is having specific tools that the researcher can collect and classify the data through them (Hafeznia, 2008). In order to obtain research final purpose, data collection has been done through these two methods:

The part which was relating to theoretical principles is done through library method, by reviewing books, articles and theses. Library method is utilized for codifying research literature and designing chapter two and also determining initial criteria for assessing brokerage firms' performance, effective factors on attracting investors and stocks liquidity. Also the part which is in connection with variables is done through tools of questionnaire. Ultimately, collected data have been modified and classified through Excel 2013 and have been analyzed through SPSS software version 18 .

\section{Data collection tools}

Questionnaire was the data collection tool of this study. 
The questionnaire of present study is the result of interview with a number of managers and senior experts about the formation and scheme of questionnaire and its design and totally the hypotheses and research questions, and they are assessed by Likert range. In order to test the reliability of research tools, the questionnaire first distributed among 7 experts and after resolving its problems the final designed questionnaire have been distributed. Also questionnaire has been utilized for determining validity of each assessment criteria for brokerage firms' performance and their role on increasing investment trust and increasing stock liquidity identified through literature review, are designed in two parts, the first part includes general questions (sex, age, education) which reviews the general information of applicants. The second part includes 16 questions in order to review effective factors on the subject and the designed research hypotheses.

\section{The assessment tool for variables of the research}

Nowadays there is different software for different fields, among such software groups, one of the most useful groups are the specific software in connection with different field of studies.

\section{Validity and reliability of research}

\section{Validity:}

In this study, data analysis is done by SPSS software version 18 , in a way that data analysis is done through three steps. First we enter the data and we store them in a file, second we choose the required analysis and third, we check the outputs and review the analysis. In present study, we have utilized validity concept. Since when experimental validation is unavailable or it is difficult to achieve a validation for a measure or a finding, we use conceptual validation, and in fact, the researcher is doing it through witness or criteria indicating the validity of measuring a concept (Khaki, 2003: 288-291), in order to identify the criteria, we have utilized the views of experts in charge of Khorasan Razavi province brokerage firms and due to the hard work, in terms of time and the way of asking questions in this research, the validity of questionnaires are highly approved.

\section{Reliability:}

Reliability is one of the technical features of measuring tools. The mentioned concept refers to how is the equality of obtained results in equal conditions and in other viewpoint, validity means whether we are testing the thing we are looking for. I this thesis, Cronbach's Alpha coefficient is 
utilized for testing reliability, which it was 0.82 , and as a result the reliability of the tool is confirmed.

\section{Data Analysis method}

In this study, for descriptive statistics we utilized criteria of average, standard deviation, variance and ... and bar charts for demographic data analysis, and data description, inferential statistics are utilized for testing hypotheses and in order to review research variables. At inferential level, in order to review hypotheses, first we check the data normality by using Kolomogrov Smirnov test and then in order to review hypotheses, in case of being normal, single sample T-test is utilized

\section{Findings:}

This study consisted of four main hypotheses:

First hypothesis: providing general and specific services by brokerage firms is effective on increasing investment trust and increasing stock liquidity.

In order to obtain relation between providing general and specific services by brokerage firms and increasing investment trust and regarding variable normality, parametric single sample T-test is utilized. Utilized questionnaire is through 5 choices of Likert range and ranks of 1 to 5 is utilized for replies. Point 1 is indicating the least value for related question and point 5 indicates the highest value, therefore, number 3 is the mean. Regarding the questions, if the variable average is more than 3 , it means there is connection between providing general services and increasing investment trust and if the average is less than 3, it means there is no relation.

Table 4-6. The results of T-Test

\begin{tabular}{|c|c|c|c|c|c|c|}
\hline \multicolumn{2}{|c|}{$\begin{array}{c}\text { Confidence interval } \\
\text { of } 95 \text { percent } \\
\text { difference }\end{array}$} & \multirow[t]{2}{*}{$\begin{array}{c}\text { Mean } \\
\text { differences }\end{array}$} & \multirow[t]{2}{*}{$\begin{array}{c}\text { The } \\
\text { significance } \\
\text { level }\end{array}$} & \multirow{2}{*}{$\begin{array}{l}\text { Degrees } \\
\text { of } \\
\text { freedom }\end{array}$} & \multirow{2}{*}{$\begin{array}{c}\text { T- } \\
\text { statistics }\end{array}$} & \multirow{2}{*}{ Mean } \\
\hline $\begin{array}{l}\text { Lower } \\
\text { bound }\end{array}$ & $\begin{array}{l}\text { Lower } \\
\text { bound }\end{array}$ & & & & & \\
\hline 0.667 & 0.413 & 0.541 & 0.000 & 106 & 8.437 & 3.54 \\
\hline
\end{tabular}

Based on T-test and the provided results within above table, $\mathrm{T}$ is 8.437 and significance level is 0.000 which is less than 0.05 and regarding that the intended variable average is more than 3 , therefore, we can 
declare with $95 \%$ certainty that there is a significant relation between providing general services and increasing investment trust, in other words, providing general and specific services is effective on increasing investment trust and increasing stock liquidity by brokerage firms.

Second hypothesis: customer orientation of brokerage firms is effecting on increasing investment trust and increasing stock liquidity.

In order to review such hypothesis, parametric single sample T-test is utilized. Results are indicated in below table:

Table 4-7. The results of T-Test

\begin{tabular}{|c|c|c|c|c|c|c|}
\hline \multicolumn{2}{|c|}{$\begin{array}{c}\text { Confidence interval } \\
\text { of 95percent } \\
\text { difference }\end{array}$} & \multirow[t]{2}{*}{$\begin{array}{c}\text { Mean } \\
\text { differences }\end{array}$} & \multirow[t]{2}{*}{$\begin{array}{c}\text { The } \\
\text { significance } \\
\text { level }\end{array}$} & \multirow{2}{*}{$\begin{array}{l}\text { Degrees } \\
\text { of } \\
\text { freedom }\end{array}$} & \multirow{2}{*}{$\begin{array}{c}\text { T- } \\
\text { statistics }\end{array}$} & \multirow[t]{2}{*}{ Mean } \\
\hline $\begin{array}{l}\text { Lower } \\
\text { bound }\end{array}$ & $\begin{array}{l}\text { Lower } \\
\text { bound }\end{array}$ & & & & & \\
\hline 0.686 & 0.450 & 0.568 & 0.000 & 106 & 9.548 & 3.57 \\
\hline
\end{tabular}

According to T-test and the obtained results in above table, $\mathrm{t}$ is 9.548 and the amount of significance level is 0.000 which is less than 0.05 and regarding the average of intended variable is more than 3 , therefore, we can declare by $95 \%$ certainty that there is a significant relation between customer-orientation and investment trust increase, in other words, customer-oriented being of brokerage firms is impacting on increasing investment trust and stock liquidity increase.

Third hypothesis: utilized latest technologies within brokerage firms are impacting on increasing investment trust and increasing stock liquidity.

In order to check this hypothesis, parametric sing sample T-test is utilized. The results of this test is indicated in below table: 
Table 4-8. The results of T-Test

\begin{tabular}{|c|c|c|c|c|c|c|}
\hline \multicolumn{2}{|c|}{$\begin{array}{l}\text { Confidence } \\
\text { interval of } \\
95 p e r c e n t \\
\text { difference }\end{array}$} & \multirow[t]{2}{*}{$\begin{array}{c}\text { Mean } \\
\text { differences }\end{array}$} & \multirow[t]{2}{*}{$\begin{array}{c}\text { The } \\
\text { significance } \\
\text { level }\end{array}$} & \multirow{2}{*}{$\begin{array}{l}\text { Degrees } \\
\text { of } \\
\text { freedom }\end{array}$} & \multirow{2}{*}{$\begin{array}{c}\text { T- } \\
\text { statistics }\end{array}$} & \multirow[t]{2}{*}{ Mean } \\
\hline $\begin{array}{l}\text { Lower } \\
\text { bound }\end{array}$ & $\begin{array}{l}\text { Lower } \\
\text { bound }\end{array}$ & & & & & \\
\hline 0.921 & 0.642 & 0.781 & 0.000 & 106 & 11.104 & 3.78 \\
\hline
\end{tabular}

based on T-test and the obtained results in above table, $\mathrm{t}$ is 11.104 , and significance level is 0.000 which is less than 0.05 and regarding the average of intended variable is more than 3 , therefore, we can declare by $95 \%$ certainty that there is a significant relation between using up-to-date technologies and increasing investment trust, in other words, using up-to-date technologies within brokerage firms is impacting on increasing investment trust and stock liquidity increase.

Fourth hypothesis: using services standardization and managerial forms is impacting on increasing investment trust and increasing stock liquidity.

In order to review hypothesis, parametric single sample T-test is utilized. Results are indicated in below table

Table 4-9. The results of T-Test

\begin{tabular}{|c|c|c|c|c|c|c||}
\hline $\begin{array}{c}\text { Confidence interval } \\
\text { of 95percent } \\
\text { difference }\end{array}$ & $\begin{array}{c}\text { Mean } \\
\text { differences }\end{array}$ & $\begin{array}{c}\text { The } \\
\text { significance } \\
\text { level } \\
\text { Lower } \\
\text { bound }\end{array}$ & $\begin{array}{c}\text { Lower } \\
\text { bound }\end{array}$ & $\begin{array}{c}\text { Degrees } \\
\text { of } \\
\text { freedom }\end{array}$ & $\begin{array}{c}\text { T- } \\
\text { statistics }\end{array}$ & Mean \\
\cline { 1 - 5 } 0.564 & 0.128 & 0.346 & 0.002 & 106 & 3.144 & 3.34 \\
\hline
\end{tabular}

Based on T-test and the obtained results in above table, $\mathrm{t}$ is 3.144, and significance level is 0.000 which is less than 0.05 and regarding the average of intended variable is more than 3 , therefore, we can declare by $95 \%$ certainty that there is a significant relation between standards, managerial styles and increasing investment trust, in other words, standards and managerial styles within brokerage firms is impacting on increasing investment trust and stock liquidity increase 


\section{CONCLUSIONS}

- First hypothesis indicates that providing general and specific services by brokerage firms is impacting on increasing investment trust and stock liquidity increase. According to the replies of questionnaire applicants and the results of T-test with 95\% certainty level there is a significant relation between independent variable and dependent variables. Therefore, brokerage firms, by providing better general and specific services (having different stock certificates, decrease of trade costs, developing branches within provinces, opening special halls, providing done assessments from confirmed firms in stock exchange to investors, establishing mutual funds for brokerage firms) can be effective on increasing investment trust and stock liquidity increase, in other words, by increasing such services, investors trust and degree of stock liquidity will increase as well.

- Based on the obtained results of testing second hypothesis with $95 \%$ certainty level, we can claim that brokerage firms, with the assist of customer-orientation variable is effective on increasing investors' trust and stock liquidity increase, therefore, the more the brokerage firms are customer-oriented, investors' trust and stock liquidity degree will increase.

- The results of third hypothesis indicate that using up to date technologies () with $95 \%$ certainty level is having significant relation with increasing investors' trust and stock liquidity increase, and according to obtained results from questionnaire and T-test of fourth hypothesis with $95 \%$ certainty level, brokerage firms can be effective on increasing investment trust and stock liquidity increase by standardizing own services and providing managerial styles. Research results are totally indicated:

- Using up to date technologies with sum of $69.2 \%$, the answers of high and very high were having the highest impact on increasing investors' trust and stock liquidity increase, and customer-orientation with sum of 61.8 , providing general and specific services $56.53 \%$ and ultimately using standards and managerial styles with $47.2 \%$, high and very high answers were having the highest impact respectively.

\section{Recommendations}

1. The results of this research can be considered by brokerage firms for making strategic decisions. Based on research findings, it is better, the brokerage experts, in order to increase investors' trust and degree of stock liquidity to provide services and required facilities for investors. 
2. Also research results will be effective on investors' decision, they shall choose brokerage firms with more focus to be more successful in their investments and to take less risk.

3. Regarding this issue that by increasing informational efficiency of the market, liquidity will increase, as a result, by the managers' control on providing better informational requirements of the market, investors can decrease risk of stock liquidity.

\section{REFERENCES:}

1. Azar Aadel,Salehabadi,Ali,Tajmir Riahi,Hamed Performance evaluation of brokerage firms based on professional performance criteria . Journal of Stock Exchange, Fall, 2012, 19: 91-103.

2. Hafeznia,Mohammadreza, Introduction to Research Methods in Human Science, (Vol. XIII edition), Samt publcation

3. Khaki, Gholamreza 2007, Research methodology with approach to the dissertation (volume third edition). Baztaab Publication

4. Sheikh Mohammad javad, Khodamoradi, Saeed,Jalilzadeh, Mohammad evaluating Tehran performance of brokerage houses and securities of using PHP and TOPSIS fuzzy, vision of financial management and accounting, Autumn, 2011, 3 .

5. Mokhtarian, Omid, 2004, Factors affecting decision making of investors, Tarbiat Modarres University, MA thesis.

6. Bhattacharya, N; Desai, H. \& K. Venkatarama, Does earnings quality affect information asymmetry? Evidence from trading costs", Contemporary Accounting Research, 2012, 29(1): 41-63.

7. Merton R.C 1987 A Simple Model of Capital Market Equilibrium with Incomplete Information, Journal of Finance

8. Robin A. "Ownership level, Ownership Concentration and Liquidity", Journal of financial market, 2007, 10: 219-248.

9. Warneryd, K. E. (2001)."Stock-market psychology: How people value and trade stocks". Cheltenham: Edward Elgar. 


\section{How to cite this article:}

Miransari M. Review the performance of brokerage firms and their role on increasing investment trust and the degree of stock liquidity. J. Fundam. Appl. Sci., 2016, 8(2S), 1606-1618. 